December 2008

\title{
Counteracting Hate Speech as a Way of Preventing Genocidal Violence
}

Wibke Timmermann

Follow this and additional works at: https://digitalcommons.usf.edu/gsp

\section{Recommended Citation}

Timmermann, Wibke (2008) "Counteracting Hate Speech as a Way of Preventing Genocidal Violence," Genocide Studies and Prevention: An International Journal: Vol. 3: Iss. 3: Article 8.

Available at: https://digitalcommons.usf.edu/gsp/vol3/iss3/8

This Articles is brought to you for free and open access by the Open Access Journals at Digital Commons @ University of South Florida. It has been accepted for inclusion in Genocide Studies and Prevention: An International Journal by an authorized editor of Digital Commons @ University of South Florida. For more information, please contact digitalcommons@usf.edu. 


\title{
Counteracting Hate Speech as a Way of Preventing Genocidal Violence
}

\author{
Wibke Timmermann \\ PhD candidate, Irish Centre for Human Rights, \\ National University of Ireland, Galway
}

\begin{abstract}
Hate speech regularly, if not inevitably, precedes and accompanies ethnic conflicts, and particularly genocidal violence. Without such incitement to hatred and the exacerbation of xenophobic, anti-Semitic, or racist tendencies, no genocide would be possible and persecutory campaigns would rarely meet with a sympathetic response in the general public.
\end{abstract}

In order to successfully prevent genocidal crimes and violence, therefore, it is indispensable to effectively address the problem of systematic incitement to hatred. While less virulent forms of hate speech may be adequately addressed by humanrights law obligations on governments to prohibit such acts, vicious, systematic, and state-organized hate propaganda should be criminalized under international law. Before discussing how hate speech can be treated as an international crime, this article assesses the most important justifications for proscribing hate speech, including the need to protect the human dignity and equality rights of the victims of such speech as well as the need to protect the public peace and the dangers of hate speech in that it may contribute to the creation of a climate of hatred and violence directed against a specific group. The article supports treating systematic incitement to hatred as a form of persecution, an approach recently upheld by the Appeals Chamber of the International Criminal Tribunal for Rwanda. Such an approach most adequately reflects the nature of hate speech and the motivations underlying its criminalization, while also respecting the important right to freedom of speech.

Keywords: hate speech, persecution, genocide, freedom of speech, human dignity

\section{Introduction: The Role of Hate Propaganda in Preparing the Ground for Genocides and Mass Violence}

Hate speech is an integral part of any state-organized persecution and serves to psychologically prepare the population of a state for certain crimes planned by its leaders. It has therefore been recognized-particularly in the years since the Rwandan Genocide- that the presence of hate propaganda may indicate an impending genocide or, at least, impending violence and conflict.

Thus, the United Nations Committee on the Elimination of Racial Discrimination (CERD) has issued a decision on the subject of early-warning procedures, in this case elaborating a "special set of indicators related to genocide" that would allow the committee "to detect and prevent at the earliest possible stage developments in racial discrimination that may lead to violent conflict and genocide." ${ }^{\text {The committee }}$ explained that the list of indicators would allow it to evaluate the presence of "factors known to be important components of situations leading to conflict and genocide." 2 Two of the indicators mentioned are of particular relevance: first, the "[s]ystematic and widespread use and acceptance of speech or propaganda promoting hatred and/or

Wibke Timmermann, "Counteracting Hate Speech as a Way of Preventing Genocidal Violence." Genocide Studies and Prevention 3, 3 (December 2008): 353-374. (C) 2008 Genocide Studies and Prevention. doi:10.3138/gsp.3.3.353 
inciting violence against minority groups, particularly in the media," and, second, "[g]rave statements by political leaders/prominent people that express support for affirmation of superiority of a race or an ethnic group, dehumanization and demonization of minorities, or condone or justify violence against a minority."3

It is well documented that major genocides of the twentieth century, such as the Holocaust and the Rwandan Genocide of $1994,{ }^{4}$ were preceded and prepared by extensive hate propaganda, a major technique of which was the dehumanization of the intended victims. In Germany, hate speech played a major role in the creation of a persecutory climate that, together with other persecutory measures, prepared the ground for the Shoah, as the District Court of Jerusalem acknowledged in the Eichmann case when it stated that "[o]ut of this soil of hatred for the Jews grew the actions of the Accused." Hitler was well aware of the powers of propaganda and, together with Joseph Goebbels, the "master manipulator of crowds,"6 exploited it to the fullest. Goebbels himself recognized the influence of the radio, without which he believed it would be impossible for the Nazis to seize and hold onto total power; he described the radio as the "first and most influential intermediary between [...] movement and nation, between idea and man,"7 and claimed that "films constitute one of the most modern and scientific means of influencing the masses." 8 He was proved right when, after seeing the propaganda film Jud Süß, which, while not directly calling for the murder of Jews, was nonetheless intended to prepare the German public for exactly that, ${ }^{9}$ some people were so frantic that they left the Berlin cinemas "screaming curses at the Jews: 'Drive the Jews from the Kurfürstendamm! Kick the last Jews out of Germany!"'10

Fifty years later, in Rwanda, symbolic language was used to stigmatize and dehumanize the Tutsi "by attributing to [them] a set of characteristic labels, each one more horrific than the next: cockroach, feudal lord, snake, subversive, enemy."11 This rejection of the Tutsi minority from the Rwandan community was achieved, moreover, by depicting them as "une race irrémédiablement dominatrice et comploteuse dont la force de nuisance transcende les frontières, au détriment de Hutu voués au rôle de victimes." 12 These characterizations created a climate of fear in which the Hutu were convinced of the need to take pre-emptive action in order to defend themselves. ${ }^{13}$

The specific danger of hate speech lies in the fact that, by dehumanizing and denigrating the victim group, it begins a "continuum of destruction." 14 This is achieved mainly by separating and excluding the victims from the community of humankind or the "human commonwealth." The victims are treated as an "out-group," and hate speech thus builds an insurmountable wall between the victim group and those remaining in the "in-group," rendering sentiments of empathy or identification with the victims impossible. ${ }^{15}$ Metaphors comparing the victimized group to insects or disease-carrying animals regularly accompany the dehumanization: in Rwanda, the Tutsi were called inyenzi, or cockroaches. ${ }^{16}$ This contributes to the creation of the climate of violence, as Jonathan Glover explains: "[s]uch images and metaphors create a psychological aura or tone which [...] may be at least as important as explicit beliefs which can be criticized as untrue."17 Similarly, David Kretzmer argues that such hostile beliefs are a "necessary condition" for racist acts. ${ }^{18}$ The capacity of human beings to convince themselves that others (the members of the victimized group) are not fellow human beings but subhumans or animals has also been noted by biologists and sociologists. Irenäus Eibl-Eibesfeldt regards the ability of humans to demonize their fellow human beings as their most dangerous characteristic, because only this can turn them into merciless killers. ${ }^{19}$ 
The dangers of vicious and systematic incitement to racial, ethnic, or religious hatred are thus readily perceived, and the need to restrict such incitement or to penalize it in one form or another is widely recognized. The best manner in which to do so and the precise constituent elements of the act are contested, however, and in certain countries, notably the United States, the debate is over whether and in what form it may be restricted at all. This article focuses on assessing the circumstances in which hate speech can be considered a crime in international law. An analysis of the philosophical debate surrounding the justifiability of criminalizing hate speech assists in adequately circumscribing and defining its components and its status under international law. First, however, a brief overview of the status of hate speech in human-rights law is provided, since this is where the international debate over hate speech has generally centered in the past.

\section{Human-Rights Law Prohibitions and Freedom of Speech}

Human-rights treaties and declarations place states under an obligation to prevent and prohibit hate speech. Article 7 of the Universal Declaration of Human Rights, for example, guarantees the right not to be discriminated against and states that "All are entitled to equal protection against any discrimination in violation of this Declaration and against any incitement to such discrimination." ${ }^{20}$ Article 20(2) of the International Covenant on Civil and Political Rights (ICCPR) specifically proscribes "any advocacy of national, racial or religious hatred that constitutes incitement to discrimination, hostility or violence." ${ }^{21}$ The ICCPR has been widely ratified; as of 18 April 2008, there are 161 states parties, ${ }^{22}$ only seven of whom have entered reservations with respect to art. $20(2) .^{23}$

The International Convention on the Elimination of All Forms of Racial Discrimination (ICERD) ${ }^{24}$ contains the most extensive and elaborate prohibition of hate speech, albeit limited to racial grounds. ${ }^{25}$ It is significant that 173 states are currently parties to this convention, ${ }^{26}$ and are thus bound by its provisions. ${ }^{27}$ Article 4 enjoins states parties to

condemn all propaganda and all organizations which are based on ideas or theories of superiority of one race or group of persons of one colour or ethnic origin, or which attempt to justify or promote racial hatred and discrimination in any form, and undertake to adopt immediate and positive measures designed to eradicate all incitement to, or acts of, such discrimination.

Specifically, states parties must criminalize "all dissemination of ideas based on racial superiority or hatred, incitement to racial discrimination, as well as all acts of violence or incitement to such acts against any race or group of persons of another colour or ethnic origin." ${ }^{28}$ In requiring states to declare incitement to hatred punishable by law - that is, to impose individual criminal responsibility for such acts-it goes much further than art. 20 of the ICCPR, which only obligates states to prohibit such acts.

Prohibiting or otherwise restricting hate speech plainly conflicts with the important right to freedom of speech. Generally, this right "include[s] freedom to seek, receive and impart information and ideas of all kinds, regardless of frontiers, either orally, in writing or in print, in the form of art, or through any other media of [one's] choice." 29 Its purpose effectively is to protect an individual's freedom to communicate in public. "Communication" encompasses "any act of symbolic expression undertaken with the intention that it be understood to be that by the public or part of the public." ${ }^{30}$ In essence, it is "a right actively to participate in and contribute to the public culture."31 
Freedom of speech is an extremely important right. Natural rights theory as developed by John Locke, for example, takes as its premise that the human being in a state of nature is fundamentally free to act, and voluntarily gives up a certain part of that freedom when entering into a social contract with other human beings. Consequently, society is justified in restraining people's only actions insofar as they injure others. ${ }^{32}$ John Stuart Mill believed that freedom of speech was a necessary instrument in the pursuit of the truth. ${ }^{33}$ Similarly, Justice Oliver Wendell Holmes argued in Abrams $v$. United States that "the best test of truth is the power of the thought to get itself accepted in the competition of the market."34 Various other arguments have been advanced in favor of freedom of speech; ${ }^{35}$ one that appears particularly relevant in the present context is based on the fact that the language used to describe the discriminating speech will necessarily be vague, which means that it may easily be abused. ${ }^{36}$ Consequently, there are important reasons for prohibiting or criminalizing only the worst kinds of hate speech, in clearly defined circumstances.

It should be noted, first of all, that certain restrictions on this right have generally been accepted in domestic jurisdictions, as well as in the jurisprudence of international courts and adjudicatory bodies such as the UN Human Rights Committee. Even the United States, traditionally the most outspoken supporter of the right to freedom of expression, recognizes that limitations are necessary in certain cases, albeit only where there is an imminent danger of harm.

The European Court of Human Rights has developed an elaborate test designed to ascertain whether or not a restriction of the right to free speech is justified. Firstly, the interference with the right must be "prescribed by law": it must have an adequate basis in domestic law, which means that it must be "adequately accessible" and "formulated with sufficient precision." ${ }^{37}$ Second, the interference must pursue a legitimate aim, that is, it must be in the interests of national security, public safety, or any other of the listed goals. Third, the restriction is subject to a proportionality test: it must be "necessary in a democratic society," which has been interpreted to imply that it must correspond to a "pressing social need" and that it must be "proportionate to the legitimate aim pursued." 38 With respect to this balancing exercise, states are accorded a certain margin of appreciation, which may vary; generally, it is likely to be broad where a case presents a controversial political, economic, or social issue (e.g., the control of obscene publications). ${ }^{39}$

The European Commission on Human Rights has held, in accordance with art. 10 of the European Convention on Human Rights, that freedom of speech can legitimately be restricted for the purposes of protecting the rights of others. Thus, in $X v$. Germany, the commission found that while $\$ 130$ of the German Criminal Code, which prohibits an individual from displaying pamphlets describing the Holocaust as a lie, involved an interference with the right to freedom of expression, it was founded on the legitimate purpose of protecting the rights of others, as it was designed to prevent a "defamatory attack" directed against the Jewish people, individually and as a group. ${ }^{40}$

The rights most likely to be infringed by hate speech are equality rights, ${ }^{41}$ such as the right to be free from discrimination, ${ }^{42}$ as well as the right to respect for human dignity. Hate speech denies the members of the victimized group the right to participate as members of equal worth in the social life of the community of the state; they are viewed as less worthy, as subhuman, and are thereby excluded. ${ }^{43}$ It discriminates against them ${ }^{44}$ and humiliates them, thus violating their human dignity, a value whose importance is expressly recognized in the Preamble to the Universal Declaration of Human Rights: "recognition of the inherent dignity and of the 
equal and inalienable rights of all members of the human family is the foundation of freedom, justice and peace in the world." In the case of hate speech, therefore, a balancing exercise must be undertaken, weighing the speaker's interest in being able to express his opinions freely against the victim's interest in preserving his or her human dignity and not being discriminated against. ${ }^{45}$

\section{The Need to Criminalize Violent and Systematic Hate Speech}

While states' obligation to prohibit hate speech is thus laid down in international human-rights conventions, under certain circumstances, the dangers of incitement to hatred and the extent of the responsibility of those who plan and engage in such speech acts for the ensuing massacres are such that mere human-rights obligations do not suffice. In certain situations, such obligations are inadequate in terms of preventing genocides and other ethnically based violence as well as in bringing to justice those who are properly seen as the true instigators and originators of such crimes. Such circumstances exist where hate speech is systematically and strategically deployed by the state or by the leadership of a state-like organization as part of a planned process of persecution directed against a particular group that is discriminated against on the basis of its members' religion, race, or ethnicity.

This article argues in favor of an approach involving the criminalization of systematic hate speech that is part of a concerted policy of persecution organized by a state or by a state-like organization. Such an approach respects the important rationales underlying the right to free speech; moreover, such an approach takes account of the two most important rationales for limiting hate speech, which are particularly pregnant in the case of the systematic incitement to hatred at issue here: the need to prevent the grave violation of human dignity that such speech entails, and the need to avert the risk of harm.

In the United States, a danger of imminent physical harm has generally been seen as the only justification for restricting freedom of speech in cases of hate speech. In the famous 1919 Supreme Court case Schenck v. United States, Justice Holmes formulated what came to be known as the "clear and present danger test": "The question in each case is whether the words used are used in such circumstances and are of such a nature as to create a clear and present danger that they will bring about the substantive evils that Congress has a right to prevent."46

Subsequently, in Brandenburg $v$. Ohio, the Supreme Court fine-tuned this theory by explaining that mere advocacy of violence and crime is not protected where it is "directed to inciting or producing imminent lawless action and is likely to incite or produce such action." 47 Clearly, then, in US jurisprudence, the only justification for restricting hate speech lies in its inherent danger; where such danger of "imminent lawless action" is not present, US courts do not regard a restriction of the speech in question as justified. ${ }^{48}$

In Germany, the public peace has also been regarded as a fundamental value, which incitement to hatred is likely to infringe, and has thus provided a justification for criminalizing hate speech in that country. The justification for limiting hate speech because of its likelihood to disturb the public peace corresponds, to a certain extent, to the American concern with "clear and present danger," in that it is concerned with the potential consequences of hate speech. The dangerousness of hate speech lies in its tendency to create a particular culture or climate-a "specific pattern of popular assumptions and beliefs stigmatizing specific groups as inferior and harmful." 49 
In Germany and internationally, the need to protect human dignity has been considered another particularly important reason for criminalizing hate speech. Thus, in several reports, the Committee on the Elimination of Racial Discrimination has evoked the "fundamental principle of respect for human dignity" when reminding states parties of their obligations under the CERD, stressing that this principle "requires all States to combat dissemination of racial hatred and incitement to racial hatred." 50

In Germany, human dignity is specifically mentioned in one of the provisions criminalizing incitement to hatred: $\S 130(2)$ of the German Strafgesetzbuch (StGB), or Criminal Code, criminalizes incitement to hatred directed against parts of the population or against a national, racial, religious, or ethnic group by means of public writings or through the media, as well as attacks on the human dignity of others by insulting, treating with scorn, or libeling parts of the population or a predetermined group through the same means of communication. Additionally, §130(1) makes it a crime to incite hatred against parts of the population or invite others to commit violent or arbitrary acts against them, ${ }^{51}$ or to attack their human dignity by insulting, maliciously heaping scorn on, or libeling them, ${ }^{52}$ if this is done in a way that is likely to disturb the public peace. Thus, the values that are to be protected by $\S 130$ are the public peace, on the one hand, and human dignity, on the other.

The concept of human dignity is of central importance within the framework of the German constitution (Grundgesetz) in that human dignity represents the fundamental principle on which the system of basic rights is founded. It is guaranteed in the first article of the Grundgesetz, which declares that an individual's dignity is inviolable. The German Constitutional Court has held that human dignity cannot be lost through undignified behavior. ${ }^{53}$ Moreover, human dignity is not measured against an individual's capacity to act in a self-determined way, nor against his or her capacity to reason, but instead is determined by humanness as such, that is, by the "menschlichen Sein angelegten potentiellen Fähigkeiten." 54

Under German law, the definition of an attack against an individual's human dignity requires that the people under attack be denied their right to live as persons of equal worth in the community of the state and that they be treated as beings who are less worthy. The attack must thus be directed against the core of their personality, which constitutes their human dignity, and not merely against particular personality traits. ${ }^{55}$ Courts have interpreted this requirement differently. While the Frankfurt District Court (Oberlandesgericht) found in a 1995 case that an attack on human dignity should primarily be interpreted as a denial of the right to life in a biological sense, that is, the right to exist as a human being as such, ${ }^{56}$ the Bavarian District Court rejected this interpretation, arguing that it is sufficient that the perpetrators deny the victims their social right to live as people of equal worth in the community. ${ }^{57}$ It appears that the latter interpretation has been preferred in the literature. ${ }^{58}$

In order to more fully understand the idea of human dignity and its significance in the context of hate speech, it is useful to draw on the theories of the philosopher Avishai Margalit, who has defined dignity as "the expression of the feeling of respect persons feel toward themselves as human beings." ${ }^{29}$ Margalit submits that human beings deserve respect because of their capacity for "radical freedom," that is, the ability to "reevaluat[e] one's life at any given moment, as well as the ability to change one's life from this moment on."60 Even the worst criminals are conceivably able to re-evaluate their lives and decide to live in an honorable manner in the future. As Margalit explains, "respecting humans means never giving up on anyone, since all 
people are capable of living dramatically differently from the way they have lived so far." ${ }^{61}$ By contrast, humiliating human beings consists in treating or seeing them as "nonhuman" or "subhuman." "62 Hate speech does exactly this; often it goes even further and engages in demonization. All these forms of humiliation involve the rejection of an individual or a group from the "human commonwealth." ${ }^{63}$ Such a rejection includes the idea of loss of control; that is, humiliation represents "the deliberate infliction of utter loss of freedom and control over one's vital interests." ${ }^{4}$ Humiliating acts "show the victims that they lack even the most minuscule degree of control over their fate- that they are helpless and subject to the good will (or rather, the bad will) of their tormentors." ${ }^{\prime 65}$ Hate speech, especially when it is part of a concerted state policy of persecution that also includes a range of other discriminatory measures, has precisely this effect: it excludes the victim group from the "human commonwealth" by means of stigmatization and, through its influence on the addressees who are incited to hatred against the victim group, demonstrates to the latter their utter helplessness and lack of control. As with other forms of humiliation, there is "a constant threat of living a life unworthy of a human being." 66 This threat is increased exponentially and becomes imminent when it is the state itself or a similarly powerful organization that engages in hate propaganda in a systematic manner as part of a general policy to persecute the victim group.

The idea of humiliation as excluding an individual from the "human commonwealth" is linked with the denial of his or her human rights, which, as we have seen, is also an effect of hate speech. Human rights are those rights that an individual possesses merely by virtue of being human, and their denial therefore expresses an attitude that regards the victim as less than human and consequently conveys his or her rejection from the human community. ${ }^{67}$

An exploration of the thought processes and emotions of those who have committed hate crimes and been actively involved in mass atrocities reveals how the stigmatization of the victims and their exclusion from the human community enabled the perpetrators to engage in these acts while simultaneously remaining convinced that these acts were necessary and, in fact, corresponded to what the prevailing morality required of them. ${ }^{68}$ As Harald Welzer writes, many German concentrationcamp officials believed themselves to be decent, upright, and morally correct agents who, while sending human beings to the gas chambers with no psychological or moral qualms (either then or later), were nonetheless upset and showed indignation when it was suggested to them years afterwards that, in their dealings with particular individuals, they had failed to act with moral integrity. ${ }^{69}$ For example, to demonstrate how he had remained a decent and compassionate man, Franz Stangl, the commander of the Treblinka camp, recounted how he granted a camp inmate's request for a more humane death for his father, who had been designated for the gas chamber, thus easing the father's (inevitable) death. ${ }^{70}$ The reason for this paradox lay, to a large extent, in the fact that they believed themselves to be doing what was necessary, as well as in the conviction that they were acting against an "out-group" created through prior stigmatization, ${ }^{71}$ which, in turn, was achieved primarily by means of hate propaganda. This conditioning of the minds of the perpetrators, which meant that the majority of them would not suffer feelings of guilt or other psychological problems, whereas those victims who survived were plagued by traumata and feelings of guilt (often for having survived while so many others perished) for years afterwards, ${ }^{72}$ can easily be recognized as extremely dangerous. As Welzer argues, the fact that the perpetrators of genocides and crimes against humanity are socio-psychologically 
normal people is more terrifying than the idea that they might have had any socialization deficits, that they were sadistic, brutalized, or the like: "Es war viel schlimmer: Sie haben einfach etwas getan, von dem sie glaubten, dass es von ihnen erwartet wurde." 73 In the case of Nazi Germany, the perpetrators' minds had been thoroughly conditioned by the prevailing Nazi morality, without which the genocide would not have been feasible. ${ }^{74}$

With these considerations in mind, we now turn to the question of whether hate speech can, under certain circumstances, also be considered an international crime, rather than merely being prohibited under international human-rights law. Antonio Cassese has defined the purpose of allocating an act the status of an international crime as the protection of "values considered important by the whole international community and consequently binding all States and individuals."75 As there is therefore a "universal interest in repressing these crimes," they are prima facie subject to universal jurisdiction. ${ }^{76}$ An argument can therefore be made that were hate speech considered an international crime, it could be prevented and stigmatized more effectively. It is submitted, however, that only the worst kind of hate speech ought to be considered an international crime, for various reasons. First, this is necessary in order to protect the important right to freedom of speech from excessive infringement. Second, because international crimes are the worst kinds of crimes, including mass killings and atrocities such as genocide and crimes against humanity, anything but the worst and most dangerous hate speech would not be comparable in gravity with the other international crimes, and consequently would not deserve to be placed in the same category. Lastly, it makes sense to deal with hate propaganda of a lesser degree through prohibition rather than criminalization, as this arguably allows for more effective prevention. This is because the burden of proof is much higher in the case of crimes than in the case of civil law prohibitions; while the prosecutor's burden in a criminal case is to prove his or her case beyond reasonable doubt, the burden of proof in a civil law case is the balance of probabilities.

\section{Hate Speech as the Crime against Humanity of Persecution}

\section{The Elements of Persecution}

The most adequate and sound approach to the criminalization of systematic hate speech is to treat it as the crime against humanity of persecution. In Kunarac, the Appeals Chamber of the International Criminal Tribunal for the Former Yugoslavia (ICTY) outlined the different chapeau elements of crimes against humanity. ${ }^{77}$ First, there must be an attack, which has been said to encompass "any mistreatment of the civilian population." "78 Second, the accused's acts must be part of the attack; this does not mean that they must be committed in the midst of the attack but, rather, requires that they not be isolated acts. ${ }^{79}$ Third, the attack must be directed against a civilian population. It need not be directed against the entire population, but it must be directed against a population rather than "a limited and randomly selected number of individuals. ${ }^{80}$ The population must be the primary object, not an incidental target. ${ }^{81}$ Fourth, the attack must be widespread or systematic. While "widespread" alludes to the "large-scale nature of the attack and the number of victims," "systematic" denotes the "organised nature of the acts of violence and the improbability of their random occurrence." 82 Fifth, the perpetrator's acts must form part of a pattern of widespread or systematic crimes directed against the civilian population, and the perpetrator must know that his or her acts fit into such a pattern. The perpetrator must possess the 
intent to commit the underlying offense and know that, or be reckless as to whether, his or her acts form part of the attack. ${ }^{83}$

The crime of persecution has been recognized as a crime against humanity since the Statute of the International Military Tribunal at Nuremberg. In Kordic and Čerkez, the ICTY Appeals Chamber summarized the elements of this crime, explaining that persecution consists of any act or omission that discriminates in fact, denies or infringes upon a fundamental right laid down in either treaty or customary law, and is carried out deliberately with the intention to discriminate on a listed ground. ${ }^{84}$ The listed grounds in the Statutes of the ICTY and the International Criminal Tribunal for Rwanda (ICTR) are political, racial, and religious grounds, ${ }^{85}$ while the Statute of the International Criminal Court adds "national, ethnic, cultural, gender [...] or other grounds that are universally recognized as impermissible under international law." 86 Furthermore, the acts must be of a gravity equal to that of other crimes against humanity. They can reach such a level of gravity if their effects are similar. ${ }^{87}$ Therefore, acts of persecution must be evaluated "in their context by looking at their cumulative effect." 88 The protected interest in the case of persecution has been held to lie in all "elementary and inalienable rights of man." 89 This is implicit in the definition of "persecution" laid down in the Rome Statute, which describes it as "the intentional and severe deprivation of fundamental rights contrary to international law by reason of the identity of the group or collectivity."90

The Tadic' Trial Chamber found that persecution included a large variety of acts that could, inter alia, be physical, economic, or judicial, so long as they infringed upon an individual's right to equal enjoyment of his or her fundamental rights. 91

\section{Hate Speech as Persecution}

International tribunals have recognized that hate speech can, if certain conditions are fulfilled, constitute the crime against humanity of persecution. In fact, this treatment of vicious hate propaganda goes back to the Nuremberg trials. The Nuremberg Tribunal convicted Julius Streicher, founder and editor of the anti-Semitic propagandist newspaper Der Stürmer, holding that his

incitement to murder and extermination at a time when Jews in the East were being killed under the most horrible conditions clearly constitutes persecution on political and racial grounds [...] and constitutes a Crime against Humanity. ${ }^{92}$

Of course, in that case, it was incitement to crimes-"murder and extermination"that was considered to constitute persecution, whereas the present argument is that incitement to hatred should be regarded as persecution.

Similarly, the ICTR found in Ruggiu that the accused had committed acts of persecution, namely

direct and public radio broadcasts all aimed at singling out and attacking the Tutsi ethnic group and Belgians on discriminatory grounds, by depriving them of the fundamental rights to life, liberty and basic humanity enjoyed by members of wider society. The deprivation of these rights can be said to have as its aim the death and removal of those persons from the society in which they live alongside the perpetrators, or eventually even from humanity itself. ${ }^{93}$

Ruggiu was convicted of both persecution and direct and public incitement to genocide for the same acts. What is particularly important about the cited paragraph is that the tribunal recognized the particular evil of hate speech, which lies not only in the danger 
that it may lead to further crimes but in the fact that it severely violates the victims' human dignity by rejecting them from the society in which they live and, eventually, even from the "human commonwealth" itself.

The United States Military Tribunal in the Ministries Case, in its judgment convicting Otto Dietrich, a Nazi propagandist who held the post of Reich press chief from 1937 and state secretary of the Ministry of Public Enlightenment and Propaganda under Joseph Goebbels from 1938 to 1945, appeared to go farther. It convicted Dietrich of crimes against humanity, holding that he implemented such crimes and participated in them through his anti-Semitic press and periodical directives. ${ }^{94}$

The case of Hans Fritzsche, one of the accused before the Nuremberg Tribunal, is particularly interesting. Fritzsche, a senior official in the Ministry of Popular Enlightenment and Propaganda and head of the ministry's Radio Division, had been charged with crimes against humanity for having "incited and encouraged the commission of War Crimes by deliberately falsifying news to arouse in the German People those passions which led them to the commission of atrocities." 95 The tribunal acquitted him, explaining, inter alia, that it was "not prepared to hold that [his broadcasts] were intended to incite the German people to commit atrocities on conquered peoples."96 Subsequently, however, a German court convicted Fritzsche and sentenced him to nine years' forced labor. ${ }^{97}$ The conviction was upheld by the court of appeals, which found that although Fritzsche had not directly called for the persecution or extermination of the Jewish people, he had nonetheless contributed in a significant way to the creation of an atmosphere among the German people that favored such persecution and extermination. ${ }^{98}$ The German court thus recognized that Fritzsche's hate speech was an integral part and, indeed, a supporting pillar of the Nazis' system of persecution.

The Draft Convention for the Prevention and Punishment of Genocide prepared by the UN Secretariat in 1947 also included an article criminalizing "[a]ll forms of public propaganda tending by their systematic and hateful character to provoke genocide, or tending to make it appear as a necessary, legitimate or excusable act."99 Hate propaganda was considered punishable where it was "charged with hatred" and "systematic, that is to say, repeated methodically," as well as public. ${ }^{100}$ Comments made by delegates during the Sixteenth Meeting of the Ad Hoc Committee, which had been established by the Economic and Social Council (ECOSOC) to prepare a draft genocide convention taking into consideration, inter alia, the Secretariat's draft convention, confirm this view. ${ }^{101}$ In arguing in favor of the criminalization of such propaganda, delegates appear to have been motivated by the need to prevent widespread and systematic propaganda of the kind employed by Nazi Germany. ${ }^{102}$ These characteristics of propaganda closely correspond to the chapeau requirement of crimes against humanity that the acts committed be part of a "widespread or systematic attack," the public nature of hate propaganda rendering it likely to be widespread.

During the subsequent debates in the Sixth Committee of the General Assembly, remarks by the Polish delegate arguing in favor of the incitement provision indicate that he viewed such incitement as a form of persecution:

$[\mathrm{H}]$ ow could protection against incitement to genocide be denied to certain groups, particularly in view of the fact that the groups to be protected by the convention were for the most part extremely weak and helpless to defend themselves against their persecutors? ${ }^{103}$ 
Various other representatives also insisted on the dangers of propaganda and the need to penalize it. ${ }^{104}$ Nonetheless, the Soviet amendment was decisively rejected, ${ }^{105}$ and the Convention on the Prevention and Punishment of the Crime of Genocide as finally adopted did not contain a provision criminalizing hate propaganda.

That hate propaganda can amount to persecution was explicitly recognized in the Jud Süß Case, which in 1949 came before the Oberster Gerichtshof für die Britische Zone, the predecessor of the German Supreme Court. The accused was a well-known film director who had frequently been given special tasks by the Goebbels as minister for propaganda. ${ }^{106} \mathrm{He}$ was, moreover, the co-author and director of the film Jud Sü $\beta$, and in that capacity was charged with having committed a crime against humanity. The Court characterized the film as a "judenfeindlicher Hetzfilm," that is, an antiSemitic film the purpose of which was to stir up hatred. ${ }^{107}$ It held that one of the hallmarks of the crime against humanity of persecution is that any particular act constituting persecution is an integral part of the general persecution. ${ }^{108}$ It was sufficient that the film aggravated the persecution of Jewish people in Germany for it to be seen as having caused their mistreatment. It therefore amounted to persecution as a crime against humanity. The damage or harm of the film lay in the fact that, first, it further denigrated the Jewish people in the opinion of the public, thereby fundamentally infringing their human rights; and, second, it incited others to commit their own acts of persecution or, at least, to acquiesce in persecutory acts. ${ }^{109}$ Moreover, it was clear that the act of the accused-that is, the production of the filmconsciously created one of the means of persecution that the Nazi regime made systematic use of. ${ }^{110}$ According to the Court, the "Mitursächlichkeit des Films für die Judenverfolgung durch hetzerische Beeinflussung der öffentlichen Meinung im judenfeindlichen Sinne als einer wichtigen Grundlage der Verfolgung und Schädigung der Juden" 111 was clear. ${ }^{112}$ The Oberste Gerichtshof recognized and emphasized that it was the general persecution, involving massive and relentless state-organized propaganda, as well as the repression of the opinions of those who thought differently, that was successful and, indeed, necessary to effect the conditioning of the Germans, to turn them against their Jewish fellow citizens, and to prevent any empathetic identification with the victims' fate. ${ }^{113}$ The Court thus underlined the crucial role of hate speech in making possible the persecutory measures that followed. Indeed, hate speech is indispensable for the realization of other persecutory acts: this is why hate speech must accompany other persecutory acts and is usually accompanied by other persecutory acts.

More than fifty years later, in 2003, the ICTR confirmed in Nahimana et al. that incitement to hatred can be a form of persecution. ${ }^{114}$ The three accused in that case all held leading positions in the Rwandan media before and during the genocide of 1994 . Ferdinand Nahimana and Jean-Bosco Barayagwiza were co-founders of the notorious Radio-Télévision Libre des Mille Collines (RTLM), and Barayagwiza was also a founding member of the Coalition pour la Défense de la République (CDR) party, while Hassan Ngeze, a journalist, was the founder and editor-in-chief of the newspaper Kangura and also a founding member of the CDR party. The ICTR Trial Chamber found that "hate speech targeting a population on the basis of ethnicity, or other discriminatory grounds," reaches the same level of gravity as the other acts that constitute crimes against humanity, and therefore amounts to persecution. ${ }^{115}$ The Trial Chamber specifically pointed out that hate speech "destroys the dignity of those in the group under attack" and emphasized that it can cause "irreversible harm." ${ }^{" 116}$ It distinguished hate speech as persecution from incitement, explaining that 
persecution "is defined also in terms of impact," and "is not a provocation to cause harm," but "is itself the harm." 117 This definition corresponds to that expounded above, that hate speech as such is harmful, in that it represents an attack on someone's dignity and humiliates the victims, and that its evil therefore does not depend on its potential to spark off acts of physical violence. The Trial Chamber explained further that the writings of Kangura and the broadcasts of RTLM "condition[ed] the Hutu population and creat[ed] a climate of harm," thereby giving birth to "the conditions for extermination and genocide in Rwanda."118 Moreover, it held that "persecution is broader than direct and public incitement, including advocacy of ethnic hatred in other forms."119 Here the Trial Chamber thus went a step further than it did in Ruggiu, where it found that incitement to genocide constituted persecution. As an example of hate speech amounting to persecution, the judgment mentions the Kangura article "A Cockroach Cannot Give Birth to a Butterfly," ${ }^{20}$ which reads in part:

\begin{abstract}
A cockroach gives birth to another cockroach. [...] A Tutsi is someone who has a sweet tongue but whose wickedness is indescribable. A Tutsi is someone whose desire for revenge is insatiable; someone who is unpredictable, someone who laughs whereas he is suffering. In our language, a Tutsi is called cockroach because he takes advantage of the night to achieve his objectives. The word Inyenzi is a reminder of the redoubtable snake whose venom is extremely poisonous. ${ }^{121}$
\end{abstract}

The Trial Chamber's findings were recently largely upheld by the ICTR Appeals Chamber, which found that hate speech directed against a group and inspired by discriminatory motives - whether on the basis of ethnicity or any other basis-violates the right to respect for the human dignity of the members of the group and thus constitutes discrimination in fact. ${ }^{122}$ The Appeals Chamber opined that it is not necessary to decide whether hate speech that does not incite violence against members of an ethnic group is in itself of a gravity equivalent to that of other crimes against humanity. ${ }^{123}$ It emphasized that each underlying act of persecution need not be of a gravity equal to that of other crimes against humanity, because the underlying persecutory acts can be considered together; the cumulative effect of all the underlying persecutory acts must to be of equal gravity as the other crimes against humanity. ${ }^{124}$ Furthermore, the context in which the underlying acts were committed is "particularly important" in determining their gravity. ${ }^{125}$ The Appeals Chamber thus correctly and significantly stressed the importance of context and the need to consider all persecutory and discriminatory acts in their entirety and to look at their cumulative effect. It found that the hate speech disseminated in Rwanda after 6 April 1994 was accompanied by calls for genocide of the Tutsi ethnic group and that all the incitement to hatred took place in the context of an extensive campaign of persecution directed against the Tutsi population, which was also characterized by acts of violence and destruction of property. ${ }^{126}$ Considered in this context, the hate speech was of a gravity equal to that of other crimes against humanity.

The Supreme Court of Canada has also held that hate speech can amount to the crime against humanity of persecution. In Mugesera $v$. Canada ${ }^{127}$ the Supreme Court had to decide whether to reinstate a deportation order against an active member of a radical Hutu party who in 1993 had successfully applied for permanent residence in Canada. The deportation order had been issued under s. 27 of the Immigration Act on the basis of a speech Mugesera had given in Rwanda in 1992, and with which, Canada's minister of citizenship and immigration had decided, he had incited murder, genocide, and hatred, thereby committing a crime against humanity. Section 27 of the Immigration Act provides for the removal after admission of a permanent resident who 
"is a member of an inadmissible class described in paragraph 19(1)"; ${ }^{128}$ Section 19(1)(j) of the same act provides that no one is to be granted admission with regard to whom there are "reasonable grounds to believe" that he or she has "committed an act or omission outside Canada that constituted a war crime or a crime against humanity within the meaning of subsection 7(3.76) of the Criminal Code and that, if it had been committed in Canada, would have constituted an offence against the laws of Canada." The Court held that the deportation order had been valid and should be reinstated. ${ }^{129}$

Defining the elements of the crime of incitement to hatred, laid down in s. 319 of the Criminal Code of Canada, the Supreme Court held that "wilful promotion of hatred" required that the accused "[have] had as a conscious purpose the promotion of hatred against the identifiable group, or [that] he or she foresaw that the promotion of hatred against that group was certain to result and nevertheless communicated the statements." ${ }^{130}$ Moreover, the speaker had to "desire that the message stir up hatred," even though it need not be proven that the statements actually resulted in the stirring up of hatred. ${ }^{131}$ With respect to the actus reus, the Court found that "hatred" refers to "emotion of an intense and extreme nature that is clearly associated with vilification and detestation," 132 while "promoting" is equivalent to "actively support[ing] or instigat[ing]" and requires "[m]ore than mere encouragement." "133 In order to determine whether or not Mugesera's statement expressed hatred, the Court considered "the understanding of a reasonable person in the context,"134 that is, "the speech's audience and [...] its social and historical context."135 The Court then turned to consider the elements of crimes against humanity. ${ }^{136}$

Finally, the Court turned to the question of whether incitement of hatred could amount to a crime against humanity, and specifically persecution. Finding that "the criminal act of persecution is the gross or blatant denial of a fundamental right on discriminatory grounds," ${ }^{37}$ the Court discussed ICTR and ICTY case law, finding that the ICTR's holding in Ruggiu suggests that "hate speech always denies fundamental rights" and that "[t]he equality and the life, liberty and security of the person of targetgroup members cannot but be affected." ${ }^{138}$ The Court reasoned that in certain cases, such denial of fundamental rights may be of a gravity equal to that of the other acts enumerated as crimes against humanity. ${ }^{139}$ Applying this reasoning to the particular case at hand, the Court concluded,

A speech such as Mr. Mugesera's, which actively encouraged ethnic hatred, murder and extermination and which created in its audience a sense of imminent threat and the need to act violently against an ethnic minority and against political opponents, bears the hallmarks of a gross or blatant act of discrimination equivalent in severity to the other underlying acts [...]. The criminal act requirement for persecution is therefore met. $^{140}$

Having found that at the time of Mugesera's speech a systematic attack directed against Tutsi and moderate Hutu was taking place in Rwanda, that the speech was directed against those groups, and that "[a] persecutory speech which encourages hatred and violence against a targeted group furthers an attack against that group," the Court held that the speech "not only objectively furthered the attack, but also fit into a pattern of abuse prevailing at that time," and consequently was part of "a systematic attack directed against a civilian population that was occurring in Rwanda at the time."141

In denying the human rights of the target group-particularly the right to be free from discrimination and the right to respect for one's human dignity-hate speech is particularly suited to be regarded as the crime against humanity of persecution, 
provided that it is systematic and is steered by the government or a similarly powerful organization. Hate propaganda supports and furthers a climate in which the commission of violent acts against the victim community is regarded as acceptable and even necessary, thus encouraging any widespread or systematic attack directed against the victim group.

This conclusion is reinforced by the considerations developed above with respect to freedom of speech concerns, where it was submitted that only the most aggravated and truly dangerous hate speech should be regarded as a crime under international law. There are valid reasons for allowing hate speech up to a certain level of gravity. It could be argued, for example, that those who engage in hate speech largely end up discrediting themselves if they are allowed to do so in public. However, whether or not this is the case depends to a considerable extent on the surrounding circumstances and the context in which the hate speech is uttered, that is, the overall state and the generally accepted particular morality prevalent in the society in question, as well as on the identity of the speaker. Where the underlying morality generally accepted by the majority of a society is characterized by tolerance, civic courage, and philanthropy, then any racist or xenophobic speech will of course be broadly received with expressions of disgust and disbelief and will not be taken seriously; in such a case, publicly disseminated hate speech will indeed discredit those who engage in it. ${ }^{142}$ On the other hand, where a society is out of balance and characterized by a particular morality marked by homophobia, racism, or ethnic or religious hatred and antagonism, hate speech is particularly dangerous, and the humiliation of members of the victim group, as well as the injury to their dignity, is particularly grave. Their vulnerability, in such a situation, is immense. Such a moral climate is generally the product of systematic persecution covering all areas of social and private life, directed against a specific group and organized by the leadership of the state or by a similar state-like organization. In order to prevent such systematic persecution, as well as worse victimization, of specific groups - up to and including genocide - it is necessary to criminalize hate propaganda organized by a state or by a similarly powerful non-state actor, in a systematic manner, as part of a concerted system of persecution involving a large variety of exclusionary measures. Aside from incitement to hatred, these include, inter alia, discriminatory legislation, forcible expulsion, deprivation of citizenship, and prohibition of intermarriage between members of the persecuted group and the rest of the population.

In Nahimana, as indicated above, the ICTR Appeals Chamber conclusively upheld the Trial Chamber's most important findings on this point, confirming that hate speech constitutes the denial of certain fundamental rights. The Appeals Chamber has explicitly recognized that hate speech involves the denial of the right to respect for the human dignity of the group under attack and constitutes discrimination in fact. It has found that where hate speech occurs together with other underlying persecutory acts, such as destruction of property and violence, and where, as a whole, their effect is equally grave as other crimes against humanity, a conviction for persecution on the basis of hate speech is appropriate.

In a number of cases, moreover, both the Trial Chamber and the Appeals Chamber of the ICTY have explicitly found that persecution consists not only of acts of physical violence but also, for instance, of such acts as destruction of property and enactment of discriminatory laws. ${ }^{143}$ Importantly, the persecutory measures imposed and executed by such criminal regimes typically also involve a concerted attack on the right to freedom of speech. This fact was explicitly recognized by the Oberster Gerichtshof für 
die Britische Zone, the same German court that convicted the director of the film Jud $S \ddot{\prime} \beta$. The Court found that the violent repression of political speech and attacks against members of a particular political party, in this case members of the Social Democratic Party, which opposed Hitler-effectively, acts of persecution directed against members of a political group-denied their most basic and natural human rights and amounted to crimes against humanity. ${ }^{144}$ The post-World War II jurisprudence therefore recognizes the central role that suppression of freedom of opinion and expression played in the Nazi system of terror and persecution. The denial of the right to express opinions hostile to the Nazi regime was intrinsic to the persecution, which in itself, of course, represented the expulsion of undesirable "others" from German society. Similarly, the Court found in the Case against L. et al. that a dishonorable pillorying or exhibition of victims was dehumanizing and amounted to a crime against humanity. ${ }^{145}$ The accused, members of the Sturmabteilung (SA) or "Brownshirts," forced a member of the Social Democratic Party and a Jewish member of the community to take part in an SA procession, during which they forced their victims to wear plates around their necks bearing dishonorable inscriptions (including the word "Schieber"-_"grafter" or "profiteer") and to be driven around in a pig-cart. ${ }^{146}$ These actions were part of a systematic persecution of Jewish people that had found its general expression in a boycott of Jewish stores in April 1933. ${ }^{147}$ It was typical of this persecution, which was executed through a system of lawlessness, arbitrariness, and violence, that the victims had no recourse to effective legal protection and were helpless to prevent what was in store for them. ${ }^{148}$ One of the purposes of the system was to disseminate fear and terror, thereby suppressing all indications of resistance against National Socialism wherever they arose, as well as to render impossible any freedom of expression and thus to uphold the pretense of unified approval on the part of the German people. ${ }^{149}$ Here the Court's judgment underscores the fact that suppression of freedom of opinion is typically also part of a system of persecution - this is important, and it indicates where the real dangers of illegitimate restrictions of freedom of expression lie. It also reveals the vital importance of freedom of expression. Illegitimate limitations of freedom of expression can themselves involve a violation of human dignity.

Systematic, persecutory hate speech is clearly harmful, as it is an inherent part of the persecutory policy, supporting, justifying, and furthering any other persecutory measures that the regime in question may be pursuing vis-à-vis the victim group. It is intrinsically harmful because it serves to further degrade and humiliate individuals who are subject to various other acts of exclusion and dehumanization, including laws depriving them of their citizenship and denying them access to various professions; expropriation of their property; and forced expulsion or being compelled them to live in ghettos, separate from other members of the wider community-all of which measures suggest to them that they are less valuable than the rest of the community and that the community needs to be protected from their harmful influence. Moreover, the primary underlying purpose of the right to freedom of speech is to protect the individual against repression by the state. In the type of case that the approach advocated here purports to address, it is the state or a state-like organization which itself engages in incitement to hatred.

Nor is such hate speech in any way conducive to discovery of the truth. In the cases envisaged here, the marketplace of ideas has been destroyed by the state itselffreedom of expression is suppressed at the same time that hatred against the persecuted group is being stirred up. Furthermore, because only the most vicious and 
organized hate speech would be criminalized, the danger that such criminalization could lead to abuse as a result of vague language or a too broad interpretation is very slim indeed.

\section{Conclusion}

History shows that hate speech typically precedes public incitement to violence and specific criminal acts, including genocide. All are part of and support an organized system of persecution that includes a variety of measures. The instigation of and specific calls for criminal acts, such as genocide, is not likely to be successful unless a climate of violence has first been created by means of hate speech.

Such a climate is achieved primarily through the demonization and dehumanization of opponents, which invariably involves a violation of their human dignity through a process of humiliation equivalent to the victim group's expulsion from the human community. Vicious and systematic state-orchestrated hate speech and propaganda must be criminalized, both because they violate human dignity, which in turn is closely connected with an infringement of the victim group's right to life, equality, and nondiscrimination, and because of the inherent danger grounded in hate speech's crucial position on the "continuum of destruction." Hate speech is an integral and crucial part of any persecutory process; it plays its part through the psychological conditioning of the perpetrators.

I have argued here that criminalization of incitement to hatred is best achieved by treating it as the crime against humanity of persecution. Dealing with it in such a way would also answer concerns about freedom of speech, because incitement to hatred would amount to persecution only if the other requirements of crimes against humanity are fulfilled-in particular, that the words in question be part of a "widespread or systematic attack." Hate speech that is less grave and that does not occur in the context of a widespread or systematic attack cannot be considered to amount to persecution and can therefore be dealt with only by means of a prohibition under international human-rights law.

\section{Notes}

1. Committee on the Elimination of Racial Discrimination [CERD], "Decision on Follow Up to the Declaration on Prevention of Genocide: Indicators of Patterns of Systematic and Massive Racial Discrimination," UN Doc. CERD/C/67/Misc.8 (19 August 2005), 1. See also Report of the Committee on the Elimination of Racial Discrimination, Supplement No. 18, UN Doc. A/54/18 (29 September 1999), para. 18(a).

2. CERD, "Decision to Follow Up."

3. Ibid., 2 .

4. It is less clear what influence hate speech had on the preparation and execution of the Armenian Genocide, but it appears that it played a less important role in that event than in the preparation of either the Holocaust or the Rwandan Genocide.

5. Israel (A.G.) v. Eichmann, 36 I.L.R. 18, para. 231 (District Court of Jerusalem, 1961).

6. R.E. Herzstein, The War That Hitler Won: The Most Infamous Propaganda Campaign in History (London: Hamish Hamilton, 1979), 59.

7. Ibid., 176.

8. Ibid., 272.

9. Ibid., 310.

10. Ibid., 426.

11. Jean Mukimbiri, "The Seven Stages of the Rwandan Genocide," Journal of International Criminal Justice 3 (2005): 823-36, 829. 
12. "An irremediably domineering and plotting race whose harmful force transcends the borders, to the detriment of the Hutu condemned to the role of victims." Jean-Pierre Chrétien, Rwanda: les médias du génocide, 2nd ed. (Paris: Éditions Karthala, 2002), 34. Unless otherwise noted, all translations are my own.

13. Prosecutor v. Nahimana et al., Judgment and sentence, ICTR-99-52-T (3 December 2003), para. 179 [Nahimana Trial Judgment].

14. Ervin Staub, The Roots of Evil: The Origins of Genocide and Other Group Violence (Cambridge: Cambridge University Press, 1989), 95.

15. Ibid., 120.

16. Nahimana Trial Judgment, para. 358.

17. Jonathan Glover, Humanity: A Moral History of the Twentieth Century (London: Pimlico, 2001), 339.

18. David Kretzmer, "Freedom of Speech and Racism," Cardozo Law Review 8 (1987): 445-513, 463. See also M. Cherif Bassiouni, Introduction to International Criminal Law (Ardsley, NY: Transnational Publishers, 2003), 727-28.

19. Irenäus Eibl-Eibesfeldt, Grundriß der vergleichenden Verhaltensforschung, 8th ed. (Vierkirchen-Pasenbach: BuchVertrieb Blank, 2004), 775.

20. Universal Declaration of Human Rights, UN General Assembly Resolution 217, UN Doc. A/810 (10 December 1948).

21. International Covenant on Civil and Political Rights, 16 December 1966, 999 U.N.T.S. 171, 6 I.L.M. 368, http://www.unhchr.ch/html/menu3/b/a_ccpr.htm (accessed 16 September 2008). The ICCPR entered into force on 23 March 1976.

22. See the list at http://www.ohchr.org/english/countries/ratification/4.htm (accessed 7 May 2008).

23. These are Australia, Belgium, Luxembourg, Malta, New Zealand, the United Kingdom, and the United States. See http://www.ohchr.org/english/countries/ratification/4_1.htm (accessed 7 May 2008).

24. International Convention on the Elimination of All Forms of Racial Discrimination, 21 December 1965, 660 U.N.T.S. 195, http://www.unhchr.ch/html/menu3/b/d_icerd.htm (accessed 16 September 2008). The convention entered into force on 4 January 1969.

25. See Mylène Bidault, "La Discrimination raciale comme infraction internationale dans la Convention des Nations Unies de 1965," in Droit international pénal, ed. Hervé Ascencio, Emmanuel Decaux, and Alain Pellet, 361-?? (Paris: Éditions A. Pedone, 2000), 361.

26. As of 21 April 2008: see http://www.ohchr.org/english/countries/ratification/2.htm (accessed 7 May 2008).

27. It is important to note, of course, that several states have made reservations to various articles of the convention and hence are not bound by the obligations contained in those articles. With respect to art. 4-the provision that will be discussed here-reservations limiting the scope or application of art. 4 in one form or another have been entered by the following fourteen countries: Australia, Austria, Bahamas, Belgium, Fiji, France, Ireland, Italy, Japan, Monaco, Switzerland, Tonga, United Kingdom, and United States.

28. ICERD, art. 4(a).

29. ICCPR, art. 19 .

30. Joseph Raz, "Free Expression and Personal Identification," Oxford Journal of Legal Studies 11 (1991): 303-24, 303.

31. Ibid., 304.

32. See David S. Bogen, "The Origins of Freedom of Speech and Press," Maryland Law Review 42 (1983): 429-65, 450-51.

33. J.S. Mill, "Of the Liberty of Thought and Discussion," in On Liberty and The Subjection of Women, 22-63 (London: Penguin Classics, 2006), 23. See also Kretzmer, "Freedom of Speech and Racism," 468.

34. Abrams v. United States, 250 U.S. 616, 630 (1919).

35. See, e.g., Bogen, "Origins of Freedom," 467-92; Frederick Schauer, "The First Amendment as Ideology," William and Mary Law Review 33 (1992): 853-69; George Anastaplo, 
"Freedom of Speech and the Silence of the Law," review of Frederick Schauer, Free Speech: A Philosophical Inquiry, Texas Law Review 64 (1985): 443; Ronald Dworkin, Freedom's Law: The Moral Reading of the American Constitution (Oxford: Oxford University Press, 1996), 195-213.

36. See Kretzmer, "Freedom of Speech and Racism,", 488-89.

37. Sunday Times v. U.K. (1979-80). 2 E.H.R.R. 245, Ser. A, No. 30, para. 49.

38. Silver v. U.K. (1983), 5 E.H.R.R. 347, Ser. A, No. 61, para. 97(c); see Susannah C. Vance, "The Permissibility of Incitement to Religious Hatred Offenses Under European Convention Principles," Transnational Law and Contemporary Problems 14 (2004): 201-52, 208-9.

39. Handyside v. U.K. (1976), 1 E.H.R.R. 737, Ser. A, No. 24, para. 57.

40. X v. Federal Republic of Germany (1982), 29 Eur. Comm. H.R.D.R. 194, 198.

41. See Robert C. Post, "Racist Speech, Democracy, and the First Amendment," William and Mary Law Review 32 (1991): 267-327, 272.

42. Kevin Boyle, "Hate Speech—the United States Versus the Rest of the World?" Maine Law Review 53 (2001): 487-502, 490.

43. See Friedrich Kubler, "How Much Freedom for Racist Speech?: Transnational Aspects of a Conflict of Human Rights," Hofstra Law Review 27 (1998): 335-76, 363.

44. On states' obligation to eradicate all forms of racial discrimination in this context, see Stephanie Farrior, "Molding the Matrix: The Historical and Theoretical Foundations of International Law Concerning Hate Speech," Berkeley Journal of International Law 14 (1996): 1-98, 6-21.

45. See Ronald Dworkin, Taking Rights Seriously (London: Duckworth, 1977), 193.

46. Schenck v. United States, 249 U.S. 47, 52 (1919).

47. Brandenburg v. Ohio, 395 U.S. 444, 447 (1969). See also R.A.V. v. St. Paul (City of), 505 U.S. 377 (1992).

48. See John P. Cronan, "The Next Challenge for the First Amendment: The Framework for an Internet Incitement Standard," Catholic University Law Review 51 (2002): 425-66, 429-41; Alan. Stephens, "First Amendment Guaranty of Freedom of Speech or Press as Defense to Liability Stemming from Speech Allegedly Causing Bodily Injury," American Law Reports Annotated, Federal 94 (1989), 26; Michele Munn, "The Effects of Free Speech: Mass Communication Theory and the Criminal Punishment of Speech," American Journal of Criminal Law 21 (1994): 433-83.

49. Kubler, "How Much Freedom," 368.

50. Report of the Committee on the Elimination of Racial Discrimination, Supplement No. 18, UN Doc. A/58/18 (1 November 2003), para. 407; Report of the Committee on the Elimination of Racial Discrimination, UN Doc. A/59/18 (2004), para. 245.

51. Strafgesetzbuch, $\S 130(1)(1)$.

52. Ibid., §130(1)(2).

53. BVerfGE 87, 209 (228).

54. "The potential abilities that are grounded in human nature." BVerfGE 39, 1 (41). See also G. Foerstner, Kollektivbeleidigung, Volksverhetzung und "lex Tucholsky": Eine Untersuchung zu Äußerungsdelikten und Meinungsfreiheit (Berlin: Arno Spitz, 2002), 165.

55. BGH NJW 1994, 1421. See also Foerstner, Kollektivbeleidigung, 184-85.

56. OLG Frankfurt, NJW 1995, 143, 144.

57. BayObLG, NJW 1995, 145, 146.

58. Foerstner, Kollektivbeleidigung, 189-91.

59. Avishai Margalit, The Decent Society, trans. Naomi Goldblum (Cambridge, MA: Harvard University Press, 1996), 51.

60. Ibid., 70. See also Jean-Paul Sartre, L’Être et le néant (Paris: Gallimard, 1976).

61. Margalit, The Decent Society, 71.

62. Ibid., 89, 104.

63. Ibid., 90.

64. Ibid., 115. 
65. Ibid., 116.

66. Ibid., 122.

67. Furthermore, the injury to an individual's dignity inflicts psychological harm on him or her, which expresses itself in "low self-esteem, seclusion and alienation." Miriam Gur-Arye, "Can Freedom of Expression Survive Social Trauma: The Israeli Experience," Duke Journal of Comparative and International Law 13 (2003): 155-202, 185. Studies on the psychological harm caused by hate speech, moreover, have found the following reactions among victims: "self-hatred, humiliation, isolation, impairment of the capacity to form close interracial relationships, and adverse effects on relationships within a given group." Kretzmer, "Freedom of Speech and Racism," 466. See also Post, "Racist Speech," 273-74. Moreover, as Margalit submits, humiliation leaves psychological scars that "heal with greater difficulty than the physical scars of someone who has suffered only physical pain." Margalit, The Decent Society, 87.

68. Harald Welzer, Täter: Wie aus ganz normalen Menschen Massenmörder werden (Frankfurt am Main: S. Fischer Verlag, 2005), 29-32.

69. Ibid., 27.

70. Ibid., 28-29.

71. Ibid., 33-34.

72. Ibid., 13.

73. "It was much worse: they simply did what they believed was expected of them." Ibid., 39.

74. Ibid., 40 .

75. Antonio Cassese, International Criminal Law (Oxford: Oxford University Press, 2003), 23.

76. Ibid.

77. Prosecutor v. Kunarac, Judgment, ICTY-96-23 (12 June 2002), para. 85.

78. Ibid., para. 86 .

79. Ibid., para. 100.

80. Ibid., para. 90.

81. Ibid., para. 91.

82. Ibid., para. 94.

83. Ibid., para. 102.

84. Prosecutor v. Kordić and Čerkez, Judgment, ICTY-95-14/2-A)17 December 2004), para. 101 [Kordic' Appeals Judgment]. See also Prosecutor v. Kupreskic', Judgment, ICTY-95-16-T (14 January 2000), para. 621 [Kupreskić Trial Judgment].

85. ICTR Statute, http://www.un.org/ictr/statute.html (accessed 17 September 2008), art. 3(h); ICTY Statute, http://www.un.org/icty/legaldoc-e/index.htm (accessed 17 September 2008), art. 5(h).

86. Rome Statute of the International Criminal Court, U.N. Doc. A/CONF.183/9 (17 July 1998), art. 7(1)(h). See also G. Witschel and W. Rückert, "Article 7(1)(h)—Crime against Humanity of Persecution," in The International Criminal Court: Elements of Crimes and Rules of Procedure and Evidence, ed. Roy S. Lee, 94-97 (Ardsley, NY: Transnational Publishers, 2001); M. Cherif Bassiouni, Crimes against Humanity in International Criminal Law, 2nd ed. (The Hague: Kluwer Law International, 1999), 327.

87. Kordić Appeals Judgment, para. 102.

88. Guénaël Mettraux, International Crimes and the Ad Hoc Tribunals (Oxford: Oxford University Press, 2005), 184; Kupreskic' Trial Judgment, para. 622; Prosecutor $v$. Vasiljević, Judgment, ICTY-98-32-T (29 November 2002), para. 247; Prosecutor v. Stakić, Judgment, ICTY-97-24-T (31 July 2003), para. 736; Prosecutor v. Nikolić, Sentencing Judgment, ICTY-94-2-S (18 December 2003), para. 110.

89. Prosecutor v. Blaskić, Judgment, ICTY-95-14-T (3 March 2000), para. 220.

90. Rome Statute, art. 7(2)(g).

91. Prosecutor v. Tadic, Opinion and Judgment, ICTY-94-1-T (7 May 1997), para. 710.

92. France et al. v. Göring et al., (1946) 22 I.M.T. 502.

93. Prosecutor v. Ruggiu, Judgment and Sentence, ICTR-97-32-I (1 June 2000), para. 22.

94. Ministries Case, 14 T.W.C. 314, 576. 
95. France et al. v. Göring et al. 526.

96. Ibid.

97. Hans Fritzsche Judgment, Aktenzeichen I/2398, Spruchkammer I, Stadtkreis Nürnberg (31 January 1947), Staatsarchiv München, SpKa Karton 475.

98. Hans Fritzsche Appeals Judgment, Ber.-Reg.-Nr. BKI/695, Berufungskammer I, Nürnberg-Fürth (30 September 1947), Staatsarchiv München, SpKa Karton 475, 10.

99. Draft Convention for the Prevention and Punishment of Genocide, UN Doc. E/447 (26 June 1947), 7 (art. 3).

100. Ibid., 33.

101. Ad Hoc Committee, Summary Records of the 16th Meeting (April 22, 1948), UN Doc. E/AC.25/SR.16 (29 April 1948), 8 (Mr. Rudzinski).

102. Ibid.

103. Eighty-Fifth Meeting, UN Doc. A/C.6/SR.85 (27 October 1948), 226 (Mr. Lachs) [emphasis added].

104. Yugoslavia: Sixty-Third Meeting, UN Doc. A/C.6/SR.63 (30 September 1948), 9

(Mr. Bartos); Poland: Sixty-Fourth Meeting, UN Doc. A/C.6/SR.64 (1 October 1948), 19-20

(Mr. Lachs); Czechoslovakia: Sixty-Sixth Meeting, UN Doc. A/C.6/SR.66 (4 October 1948), 30 (Mr. Prochazka); USSR: Sixty-Seventh Meeting, UN Doc. A/C.6/SR.67 (5 October 1948), 39 (Mr. Morozov), and Eighty-Sixth Meeting, UN Doc. A/C.6/SR.86 (28 October 1948), 245 (Mr. Morozov); Venezuela: Eighty-Fourth Meeting, UN Doc. A/C.6/SR.84 (26 October 1948), 208 (Mr. Pérez Perozo); Greece: Eighty-Sixth Meeting, UN Doc. A/C.6/SR.86 (28 October 1948), 245 (Mr. Spiropoulos); France: ibid., 246 (Mr. Chaumont); Haiti: ibid., 247 (Mr. Demesmin).

105. The first part of the amendment, penalizing propaganda "aimed at inciting racial, national or religious enmities or hatreds," was rejected by twenty-eight votes to eleven, with four abstentions; the second part, criminalizing propaganda "aimed at provoking the commission of acts of genocide," was rejected by thirty votes to eight, with six abstentions. Eighty-Seventh Meeting, UN Doc. A/C.6/SR.87 (29 October 1948), 253.

106. Strafsenat, Judgment of 12 December 1949 against H., StS 365/49, Entscheidungen des Obersten Gerichtshofes für die Britische Zone in Strafsachen, vol. 2 (Berlin: Walter de Gruyter, 1950), 291.

107. Ibid., 293.

108. Ibid., 296.

109. Ibid.

110. Ibid., 297.

111. "The film's shared responsibility for the persecution of the Jews through influencing the public opinion, in an inciting manner, marked by hostility towards the Jews, as an important foundation for the persecution and harming of the Jews."

112. Strafsenat, Judgment of 12 December 1949 against H., 300.

113. Ibid., 299.

114. See Catharine A. MacKinnon, "Prosecutor v. Nahimana, Barayagwiza \& Ngeze," American Journal of International Law 98 (2004): 325-30, 328. See also Prosecutor $v$. Bagosora et al., Decision on Motions for Judgement of Acquittal, ICTR-98-41-T (2 February 2005), para. 32.

115. Nahimana Trial Judgment, para. 1072.

116. Ibid.

117. Ibid., para. 1073.

118. Ibid.

119. Ibid., para. 1078.

120. Ibid.

121. Ibid., para. 179 .

122. Nahimana et al. v. Prosecutor, Judgment, ICTR-99-52-A (28 November 2007), para. 986. 123. Ibid., para. 987. 
124. Ibid.

125. Ibid.

126. Ibid., para. 988.

127. Mugesera v. Canada (Minister of Citizenship and Immigration), 2005 SCC 40. For commentary see Joseph Rikhof, "Hate Speech and International Criminal Law: The Mugesera Decision by the Supreme Court of Canada," Journal of International Criminal Justice 3 (2005): 1121-33.

128. Immigration Act, R.S.C. 1985, c. I-2, s. 27(1)(a).

129. The Supreme Court thereby overturned a unanimous decision by the Federal Court of Appeal, 2003 FCA 325, dismissing an appeal by the minister of citizenship and immigration of the Appeal Division of the Immigration and Refugee Board's holding that there was no basis for allegations that Mugesera was guilty of crimes against humanity or of misrepresentation in his immigration application and allowing Mugesera's appeal against the Appeal Division's holding that the allegations against him in respect of incitement to murder, genocide, and hatred were justified. The Federal Court of Appeal found, inter alia, that Mugesera's speech did not meet the requirements of a crime against humanity, as there was "no evidence that the speech was part of a widespread or systematic attack." According to the court, there was "nothing in the record to indicate that the massacres which had taken place up to then were co-ordinated and for a common purpose," nor was there "evidence in the record that Mr. Mugesera's speech was part of any strategy whatever," and that "the Minister ha[d] not established that Mr. Mugesera was prompted by ethnic considerations." Ibid., para. 58 .

130. Mugesera, para. 104.

131. Ibid.

132. Ibid., para. 101, citing R. v. Keegstra (1990), 3 S.C.R. 697, 777.

133. Mugesera, para. 101, referring to Keegstra, ibid.

134. Mugesera, para. 103, referring to Canadian Jewish Congress v. North Shore Free Press Ltd. (1997), 30 C.H.R.R. D/5 (B.C. H.R.T.), para. 247.

135. Mugesera, para. 103.

136. The Court's analysis essentially corresponds to the analysis above, that is, a prohibited act must have been committed, which was part of a widespread or systematic attack "directed against any civilian population or any identifiable group of persons;" and the accused knew of the attack and knew that or was reckless as to whether his act comprised part of the attack. Ibid., para. 119.

137. Ibid., para. 145.

138. Ibid., para. 147.

139. Ibid.

140. Ibid., para. 148.

141. Ibid., para. 169.

142. It is of course true that even in a generally tolerant society there will almost inevitably be certain individuals or groups who engage in racist or xenophobic speech, and there will also be individuals or groups who are susceptible to and will be influenced by such speech. The argument here is based on the general outlook of the majority —or, in any case, $a$ considerable proportion - of a society's members. Thus, compare Germany today with Germany in the 1930s, marked as it was by a persecution of Jewish citizens that extended to all areas of public and private life: e.g., Saul Friedländer, The Years of Persecution: Nazi Germany and the Jews 1933-1939 (London: Orion Books, 2007).

143. See, e.g., Prosecutor v. Blagojević and Jokić, Judgment, ICTY-02-60-T (17 January 2005), paras. 593-94; Kordić Appeals Judgment, para. 108; Tadić Trial Judgment, para. 710; Prosecutor v. Simic, Judgment, ICTY-95-9-T (17 October 2003), para. 58.

144. Strafsenat, Judgment of 8 January 1949 against G., StS 109/48, Entscheidungen des Obersten Gerichtshofes für die Britische Zone in Strafsachen, vol. 1 (Berlin: Walter de Gruyter, 1948), 249. 
145. Strafsenat, Judgment of 14 December 1948 against L. et al., StS 37/48, Entscheidungen des Obersten Gerichtshofes für die Britische Zone in Strafsachen,Vol. 1 (Berlin: Walter de Gruyter, 1948), 229-34.

146. Ibid., 229-30.

147. Ibid., 230.

148. Ibid.

149. Ibid. 